\title{
Analysis of Zooplankton Diversity and Limnological Parameters of Salchapra Anua, an Oxbow Lake in Silchar, Assam
}

\author{
Masuma Ferdaush Laskar, Sulata Kar, Papia Das, Uma Das, Satyajit Das \\ Devashish Kar \\ Department of Life Science and Bioinformatics, Assam University, Silchar-788011
}

\begin{abstract}
Zooplankton diversity and Limnological parameters are the most important criteria for determining the suitability of an aquatic ecosystem for any kind of aquacultural programme. Water quality of the freshwater habitats provides information about the existing resoureces which depend on physico-chemical parameters and biological features. Some of the limnological parameters and Zooplankton composition of Salchapra Anua was studied for a period of six months from October, 2016 to March, 2017. The limnological parameters of the study site was found to be highest during the month of October, 2016. A total of 15 taxa belonging to three groups were recorded during the investigation of which 5 taxa were from Cladocera group, 4 from Copepoda and 6 taxa from Rotifera group. The highest Zooplankton abundance was recorded from the site during the month of October, 2016 and lowest during the month of February, 2017. Cladocera contribute highest percentage of 43\% of the total Zooplankton composition followed by $42 \%$ of Rotifera and 15\% of Copepoda. Presence of highest percentage of Cladocera again depicts the better condition of the water body and can be used for aquacultural program.
\end{abstract}

Keywords: Zooplankton, Limnology, Cladocera, Anиa, Aquaculture.

\section{Introduction}

Limnology is the study of all aquatic system, both lentic and lotic fresh, fresh and saline including lakes, wetlands, marshes, bogs, ponds, reservoirs, streams, rivers, oceans etc. with regard to their physical, chemical and biological characteristics(Kar,2007). Wetlands being one of the most productive ecosystems are crucial for biodiversity conservation. Wetlands of Northeast India is a house to diverse kind of biota living in it and a support a large range of organism living in it. Among these Zooplankton are minute aquatic free floating microscopic organism, which are grazers on phytoplankton and act as larger food source of larval and higher vertebrates and invertebrates including carnivorous and omnivorous fishes (Goswami and Mankodi 2012). They are related to the growth of juvenile fishes and are also play important role in the transfer of energy from the primary phytoplankton to higher trophic levels (Ismail and Zaidin, 2015). Physico-chemical parameters are one of the most appropriate source to measure the water quality of a aquatic body. A slight change in physico chemical aspect of a water body brings about a corresponding change in the relative composition and abundance of the organisms on that water body. The Zooplankton community fluctuates according to the physico-chemical parameters and the relative environment of the water body especially the Rotifers as they are known to change immediately along with the change in water quality (Dede and Deshmukh, 2015).

Information on Zooplankton diversity of the country is scanty. Some reports from Khan $(2002,2003)$; Ganesen and Khan(2008) from Southern Bengal;Sharma(2005,2010); Sharma and Sharma(2002,2008); Nimbalkar et al., (2013); Bhat et al., (2014); Dede and Deshmukh,( 2015);Balakrishna et al,(2013); Sharma et al., (2015); But the studies on zooplankton in north-east part of the country, especially in South Assam is scanty except some worth mentioning works in recent years that Kar (2007,2013); Kar and Barbhuiya (2004); Kar and Kar (2013,2016a,b);Das et al.,(2014);Das and Kar (2013,2016); Kar et al., (2015); Kar et al.,(2016). Since, recent years, the Salchapra Anua has been a victim of different problems like sedimentation, urbanization and growth of various small scale mills; thereby, leading to its siltation, eutrophication, including health problems to fishes, notably, Epizootic Ulcerative Syndrome or EUS (Kar,2013)The present investigation has been undertaken to determine the diversity and abundance of Zooplankton community in relation to the physicochemical parameters of the study site.

\section{Material And Methods}

Study site: The present study was conducted on Salchapra Anua (area, $1125000 \mathrm{~m}^{2}$ at FSL and $525000 \mathrm{~m}^{2}$ at DSL) lying between $24^{\circ} 49^{\prime} 28.8^{\prime \prime} \mathrm{N}$ and $92^{\circ} 39^{\prime} 43.9^{\prime \prime} \mathrm{E}$ and situated $20 \mathrm{k} . \mathrm{m}$ from the Silchar main town. The name of the Anua is the ' 66 number Barak Nadi Anua' at Salchapra part-II. The Anua is formed about 100 years ago by the meandering portion of the river Barak. The average depth of the Anua is about $7 \mathrm{~m}-9 \mathrm{~m}$, maximum depth is $12 \mathrm{~m}$ at the deepest zone during rainy season. 
Sample collection and analysis: The study was carried out in Salchapra Anua for a period of six months from October, 2016 to March, 2017. Water quality of the wetland was studied following standard method of APHA, 2005. The sample was collected weekly from the site following the standard methods and literature of Battish,1992.The Zooplankton sample was collected from the site during early in the morning (6am to 7am)for a period of six months following standard methods and literature of Battish, 1992. The sample were then brought to laboratory for further qualitative verification and quantitative estimation. Quantitative samples were collected by filtering $100 \mathrm{ml}$ water. The collected species were then filtered and preserved in 5\% formalin solution for taxonomic identification and kept in cold and dark place. Analysis was done on a Sedgwick Rafter Counting cell, under a light microscope. The zooplanktons were then identified following standard literature of Edmondson 1959; Battish, 1992; Michael and Sharma, 1998; Sharma, 1998; Sharma and Sharma, 2008.

\section{Results And Discussion:}

During the study period, water temperature, pH, Dissolved Oxygen (DO), Free Carbon Dioxide $\left(\mathrm{FCO}_{2}\right)$, Total Alkalinity were measured monthly for six months. Their values are depicted in Table 1. The limnological parameters of the study site was found to be highest during the month of October, 2016. $\mathrm{pH}$ of the Anua was found to be at par during the six months study period. DO and $\mathrm{FCO}_{2}$ were found to be highest during the month of October and lowest during the winter months i.e, December, 2016 - January, 2017. This depicts that the water body used as our study site is very much good for an aquacultural programme to carry on.

Table 1: Physico-chemical parameters of Salchapra Anua during the study period

\begin{tabular}{|l|l|l|l|l|l|l|}
\hline PARAMETERS & OCT-16 & NOV-16 & DEC-16 & JAN-17 & FEB-17 & MAR-17 \\
\hline Water Temperature ( $\left.{ }^{0} \mathrm{C}\right)$ & 25 & 23 & 20 & 19 & 21 & 24 \\
\hline pH & 6.9 & 6.8 & 6.8 & 6.9 & 6.8 & 6.8 \\
\hline Dissolved Oxygen, DO $(\mathrm{mg} / \mathrm{l})$ & 7.3 & 7.1 & 7 & 7 & 7.1 & 7.1 \\
\hline Free Carbon Dioxide, FCO 2 (mg/l) & 0.9 & 0.7 & 0.6 & 0.5 & 0.6 & 0.5 \\
\hline Total Alkalinity $(\mathrm{mg} / \mathrm{l})$ & 57 & 56 & 53 & 55 & 56 & 57 \\
\hline
\end{tabular}

The present study reveals the Zooplankton composition and diversity of Salchapra Anua during the study period (Table 2). A total of 15 taxa belonging to three groups were recorded during the investigation of which 5 taxa were from Cladocera group, 4 from Copepoda and 6 taxa from Rotifera group. The highest Zooplankton abundance was recorded from the site during the month of October, 2016 and lowest during the the month of February, 2017. On a similar study in three different kind of freshwater waterbodies in Penang Island, Ismail and Zaidin, 2015 reported highest Zooplankton abundance on the month of November while the lowest in the month of February. Among all the Zooplankton groups, Rotifera was reported to be dominant among other groups during the period of investigation consisting of 6 taxa of which Filinia sp. shows highest abundance and Keratella sp. shows the lowest abundance all throughout the six months study. In Cladocera group, Moina sp. shows highest and Bosmina sp. shows lowest abundance while Copepoda group, Mesocyclops sp. shows highest abundance and Microcyclops sp. shows lowest abundance throughout the study period. Compared to all other taxa, Filinia sp. of Rotifera group were found to dominate the population of Zooplankton. Abundance of Rotifera group may indicate the presence of dissolved solids in the study site, as they are known to increase the growth of minor phylum of Zooplankton in the water body (Goswami and Mankodi, 2012).

Fig 1 shows the percentage composition of Zooplankton in the study during the period of investigation. Cladocera contribute highest percentage of $43 \%$ of the total Zooplankton composition followed by $42 \%$ of Rotifera and $15 \%$ of Copepoda. Presence of highest percentage of Cladocera again depicts the better condition of the water body and can be used for aquacultural program. Fig 2 depicts the graphical representation of the abundance of three different groups during the study period. Cladocera shows highest abundance among other groups of Zooplankton present in the study site. Cladocera were found to be abundant during the month of October, 2016 whereas Copepoda and Rotifera was also found abundantly during the month of October, 2016. Lowest abundance of Zooplankton composition were found to be during the month of February, 2017.

Table 2: Monthly composition of Zooplankton groups in Salchapra Anua during the study period.

\begin{tabular}{|l|l|l|l|l|l|l|}
\hline ZOOPLANKTON & OCT-16 & NOV-16 & DEC-16 & JAN-17 & FEB-17 & MAR-17 \\
\hline CLADOCERA & & & & & & \\
\hline Diaphanosoma sp. & 12 & 10 & 11 & 8 & 10 & 10 \\
\hline Sida sp. & 8 & 8 & 9 & 7 & 6 & 7 \\
\hline Moina sp. & 21 & 17 & 20 & 14 & 10 & 10 \\
\hline Chydorus sp. & 5 & 3 & 3 & 1 & 1 & 3 \\
\hline Bosmina sp. & 2 & 3 & 2 & 1 & 1 & 2 \\
\hline TOTAL & $\mathbf{4 8}$ & $\mathbf{4 1}$ & $\mathbf{4 5}$ & $\mathbf{3 1}$ & $\mathbf{2 8}$ & $\mathbf{3 2}$ \\
\hline COPEPODA & & & & & & \\
\hline Mesocyclops sp. & 8 & 7 & 8 & 5 & 3 & 7 \\
\hline Microcyclops sp. & 2 & 1 & 0 & 1 & 0 & 0 \\
\hline
\end{tabular}




\begin{tabular}{|l|l|l|l|l|l|l|}
\hline Thermocyclops sp. & 3 & 2 & 2 & 2 & 2 & 3 \\
\hline Neodiaptomus sp. & 7 & 5 & 2 & 1 & 1 & 5 \\
\hline TOTAL & $\mathbf{2 0}$ & $\mathbf{1 5}$ & $\mathbf{1 2}$ & $\mathbf{9}$ & $\mathbf{6}$ & $\mathbf{1 5}$ \\
\hline ROTIFERA & & & & & & \\
\hline Brachionus sp. & 4 & 3 & 3 & 5 & 3 & 2 \\
\hline Lecane sp. & 2 & 1 & 0 & 2 & 1 & 1 \\
\hline Keratella sp. & 2 & 0 & 0 & 6 & 4 & 1 \\
\hline Asplanchna sp. & 7 & 5 & 8 & 9 & 7 & 9 \\
\hline Testudinella sp. & 6 & 8 & 8 & 18 & 5 \\
\hline Filinia sp. & 22 & 19 & 16 & $\mathbf{3 5}$ & 15 \\
\hline TOTAL & $\mathbf{4 3}$ & $\mathbf{3 6}$ & $\mathbf{3 5}$ & $\mathbf{3 8}$ & $\mathbf{3 3}$ \\
\hline
\end{tabular}

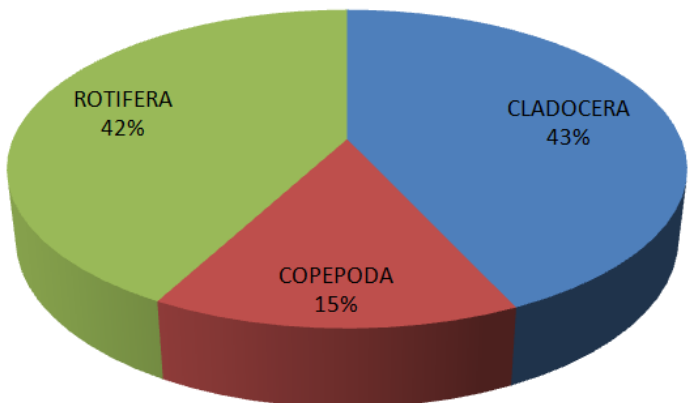

Fig 1: Percentage Composition of Zooplankton in Salchapra Anua during the study period

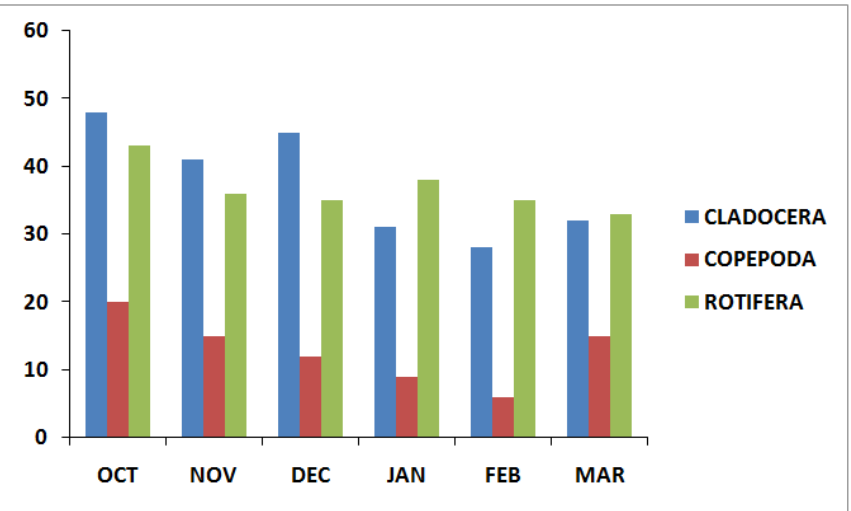

Fig 2: Abundance of different groups of Zooplankton in Salchapra Anua during the study period

\section{Conclusion}

Salchapra Anua is a river-formed wetland of Cachar, Assam. It is also used for various aquacultural program as well as carries a great scenic beauty and thus can be used for tourism. Though the present study was of small duration but it was able to slightly depict the recent scenario of the Anua. Presence of good abundance of Cladocera is very much appreciable as they are known to be the staple food of larvae of various culturable fishes. But increasing abundance of Rotifera may be an indication to the increase of pollutants to the water body. Thus, the inhabitants and the authority should take care and educate peoples residing nearby to preserve and maintain the authenticity of the Anua.

\section{References}

[1]. APHA. (2005). Standard methods for the examination of water and waste water $21^{\text {st }}$ Edn Washington DC,AUC.

[2]. Battish, S.K. (1992). Freshwater zooplankton of India. Oxford and IBH publishing Co., New Delhi.

[3]. Balakrishna,D.; Mahesh,T.; Samatha. D and Ravinder Reddy, T.(2013)Zooplankton Diversity Indices Of Dharmasagar Lake, Warangal District (A.P.). International Journal of Research in Biological Sciences; 3(3): 109-111.

[4]. Bhat, N. A.; Wanganeo, A. and Raina, R. (2014). The composition and diversity of net zooplankton species in a tropical waterbody (Bhoj Wetland) of Bhopal, India. International Journal of Biodiversity and Conservation; 6(5): 373-381.

[5]. Das, P. and Kar, D. (2013). Studies on zooplankton diversity and physicochemical parameters of Ramnagar annua, Assam. International Journal of Current Research; $5:$ 3058-3062.

[6]. Das, U. and Kar, D. (2013).A Comparative Study On Qualitative And Quantitative Analysis Of Zooplankton In Relationship With Physico-Chemical Properties Of Water Between Karbala Lake And Baram Baba Pond Of Cachar District, Assam. International Journal of Current Research; $5: 3038-3041$.

[7]. Das, B.K.; Boruah, P. and Kar, D. (2014). Study of seasonal variation of water quality of River Siang in Arunachal Pradesh, India. IOSR Journal of Environmental Science, Toxicology and Food Technology 8 (2): 11-20. 
[8]. Das, B.K. and Kar, D. (2015). Physico-chemical parameters and drainage types of River Siang in Arunachal Pradesh, India. In: Mishra GC (Ed.) Conceptual Framework and Innovations in Agroecology and Food Sciences, Krishi Sanskriti Publications, New Delhi, India.3-56.

[9]. Das, P.and Kar, D.(2016). Composition, abundance and diversity of zooplankton population from three different wetlands from Barak Valley, Assam. International Journal of Applied and Natural Sciences ( IJANS );5(5): 2319-4014.

[10]. Dede, A.N. and Deshmukh, A.L. (2015). Study on Zooplankton Composition and Seasonal Variation in Bhima River Near Ramwadi Village, Solapur District (Maharashtra), India. Int.J.Curr.Microbiol.App.Sci ; 4(3): 297-306

[11]. Edmondson, W.T. (1959). Rotifera, in W.T. Edmondson (ed.). Fresh-water Biology, 2nd edn. Newyork: John Wiley.

[12]. Ganesan, L. and Khan R. A. . (2008). Studies on the Ecology of Zooplankton in a Floodplain Wetland of West Bengal, India. In Sengupta, M. and R. Dalwani (Eds) Proceedings of Taal2007: The 12 ${ }^{\text {th }}$ World Lake Conference: 67-73.

[13]. Goswami, A.P. and Mankodi, P.C. (2012). Study on Zooplankton of Fresh Water Reservoir Nyari - II Rajkot district, Gujarat, India. ISCA Journal of Biological Sciences; 1(1):30-34

[14]. Ismail, A. H. and Zaidin, S. A. (2015). A comparative study of Zooplankton diversity and abundance from three different types of water body. 2nd International Conference on Agriculture, Environment and Biological Sciences (ICAEBS'15) August 16-17, 2015 Bali (Indonesia).

[15]. Kar, D and Barbhuiya, M.H. (2004). Abundance and diversity of zooplankton in Chatla Haor, a floodplain wetland in Cachar district of Assam. Environment and Ecology, 22 (1): 247-248.

[16]. Kar, D. (2007). Fundamentals of Limnology and Aquaculture Biotechnology. Daya Publishing House, xiv+609.

[17]. Kar, S. and Kar, D. (2013). Studies on zooplankton diversity of an oxbow lake of South Assam, India. International Journal of Current Research, 5(12):3652-3655.

[18]. Kar, D. (2013). Wetlands and Lakes of the World. Springer, London, $x x x+687$.

[19]. Kar,D.(2015).Epizootic Ulcerative Fish disease Syndrome,.Elsevier(Academic Press,USA), xix+293.ISBN:9780128025048

[20]. Kar D. (2016). Wetland, rivers, fish, plankton resource and fish diseaseand aquaculture in north-east India: An overview. Lake 2016: Conference on Conservation and Sustainable Management of Ecologically Sensitive Regions in Western Ghats.

[21]. Kar, S. and Kar, D. (2016a). Zooplankton Diversity in A Freshwater Lake Of Cachar, Assam. International Journal of Applied Biology and Pharmaceutical Technology; 7(1): 301-305.

[22]. Kar, S. and Kar, D. (2016b). Zooplankton Diversity in A Freshwater wetland Of Cachar, Assam. International Journal of advanced Biotechnology and Research. 7(2); 614-620.

[23]. Khan, R. A. (2002). The ecology and faunal diversity of two ox-bowlakes of southeastern West Bengal. Record Zoological Surey of India. Occasional Paper No. 194: 1-104.

[24]. Khan, R. A. (2003). Faunal diversity of zooplankton in freshwater wetlands of south-eastern West Bengal. Record Zoological Surey of India. Occasional Paper No. 204: 1-107.

[25]. Michael, R.G and Sharma, B.K (1998). Indian Cladocera (Crustacea: Branchiopoda: Cladocera) Fauna of India and Adjacent Countries. Zoological Survey of India. 262.

[26]. Nimbalkar, R. K. Kamtikar, V. N.; Shinde, S. S. and Wadikar, M. S. (2013). Studies On Zooplankton Diversity; In Relation To Water Quality Of Ambe Ghosale Lake Of Thane City, (Ms) India. Bioscience Discovery; 4(1):124-127.

[27]. Sharma, B.K. (1998). Freshwater Rotifers (Rotifera: Eurotatoria). Fauna of West Bengal. State Fauna Series; 3(11): 341-461.

[28]. Sharma, B.K. (2005). Rotifera communities of flood plain lakes of the brahmaoutrabbasin of lower Assam (NE India: biodiversity, distribution and ecology. Hydrobiology.533: 1-3.

[29]. Sharma, B.K. and Sharma, S. (2008) Zooplankton diversity in floodplain lakes of Assam. Records of Zoological Survey of India. Occasional paper no 290: 1-307.

[30]. Sharma, B.K. (2010). Rotifera communities of Deepor Beel, Assam, India: richness, abundance and ecology. Journal of threatened Taxa. 2(8): 1077-1086

[31]. Sharma, K. K.; Kour, S. and Antal, N. (2015). Diversity of Zooplankton and Macrobenthic Invertebrates of Two Perennial ponds in Jammu Region. Journal of Global Biosciences; 4(2): 1382-1392. 